\title{
TRANSFORMATION OF THE PASSIVE ELECTORAL RIGHT IN THE RUSSIAN FEDERATION AFTER THE PROTESTS “FOR FAIR ELECTIONS" OF 2012
}

\begin{abstract}
This article examines the transformation of the passive electoral right within the Russian Federation after the acts of protest "For Fair Elections". The author highlights that the transformation of this right retained its centralized vector, imitating the democratization of the electoral system. The analysis of the legislation and the political practice demonstrates that the limitations of the Russian citizens' passive electoral right contradicts the norms of international law and the Constitution of the Russian Federation; in the area of political practice they infringe upon the essential principles of electoral right, including government non-involvement into the electoral process and equality of the voters. The mass protests of 2011-2012 did not produce changes, nor gave the citizens the opportunity to be elected as officials of the branches of government, and were further restricted by additional limitations that have a significant impact in the area of the selective functions of the government. The electoral system of the Russian Federation continued the transformation in the direction of interests of the federal president and the highest government bureaucracy, which leads to a collapse of the feedback system, degradation of Russian politeia, and imitation of the right to be elected.
\end{abstract}

Keywords: Limitation of rights, passive electoral right, centralization, authoritarianism, presidentialism, delegate democracy, elections, representative democracy, constitutionalism, democracy.

Аннотация: В данной статье рассматривается преобразование пассивного избирательного права в Российской Федерации после акиий протеста "За честные выборы". Автор подчеркивает, что трансформация избирательного права на современном периоде сохранила иентрализованный вектор. Анализ законодательства и политической практики показывает, что ограничения пассивного избирательного права граждан России противоречат нормам международного права и Конституции Российской Федерачии; политическая практика характеризуется нарушением принципов, запрещающих органам исполнительной власти принимать участие в избирательном процессе, а также нарушением принципа равенства избирателей. Массовые протесты 2011-2012 привели к позитивным изменениям в избирательном процессе лишь отчасти, так как был снят ряд ограничений на участие в избирательном проиессе. В тоже время был введен ряд ограничений, которые оказывают существенное влияние в области избирательного права. Избирательная система Российской Федерации продолжила трансформацию в направлении централизации и защиты интересов государственной власти, что приводит к краху системы обратной связи и деградачии российского гражданского общества.

Ключевые слова: Пассивное избирательное право, централизация, авторитаризм, президентское правление, представитель демократии, выборы, представительная демократия, ограничение прав, конституционализм, демократия.

T he acts of protest "For Fair Elections" that took place in the large cities of Russia have led to the transformation of the passive electoral right affecting all levels of the functionality of the politeia. Although posed as concession to the non-party opposition and citizen activists, the electoral reforms only eased the pressure on the government and ensured the preservation of the existing system.

In May of 2012 a Federal Law was passed exempting political parties from the need to collect signatures to run for office in parliamentary elections [1], which realized the idea of the Russian president voiced in his address of the Federal Council on December 22 $2^{\text {nd }}, 2011$ - to decrease the number of voter signatures from 2 million to 300 thousand for self-promoted candidates, and down to 100 thousand for the non-parliament parties.

On December $4^{\text {th }}, 2012$ Vladimir Putin has signed a new Federal legislation "On the Formation of the Federation Council of the Federal Assembly of the Russian Federation" [2], which did not change the mechanism of the indirect elections of the members of the Federal Council from the original parliaments, but used the idea of electing the members of the Federal Council from the head of the subject of the Russian Federation: the head of the subject of the Russian Federation during registration of the subject of the Russian Federation at the electoral committee sends three candidates to the "upper" chambers of the Federal Assembly, one of whom he will later appoint should he get 
elected. The information on the proposed candidates by the head of the executive branch of government of the subject of the Russian Federation is then placed in the voting centers during the elections, which allowed drawing a parallel with the electoral institution.

According to the new law «On the Election of Deputies of the State Duma of the Federal Assembly of the Russian Federation» from February $22^{\text {nd }}, 2014$ [3] the proportional system of elections of deputies for the lower chambers of the Russian parliament was replaced by the proportional/ majority electoral system -225 deputies are elected in the single member districts (one district - one deputy), and 225 deputies are elected in federal electoral district proportional to the number of the electorates submitted for the federal lists of candidates for the position of a deputy of the State Duma. The changes to the electoral system from proportional to a mixed system have expanded the political rights of the Russian citizens, giving them an opportunity for self-promotion. In addition to that, the electoral bar was lowered from $7 \%$ to $5 \%$ for the political parties, and the Federal Law No. 41-FZ from May 2 $2^{\text {nd }}, 2012$ relieved all of the political parties from the requirement to gather signatures for the" lower" chamber of the Russian parliament and the regional legislatures.

The protest movement has forced the government to change the mechanism of actual appointment of the heads of executive branch of power of the subjects of the Russian Federation to a "national election". According to the passed on May $2^{\text {nd }}, 2012$ Federal Law No. 40-FZ, the political parties as well as citizens (by way of self-promotion) have received the right to propose a candidate for the highest post of the subject of the Federation (a head of the highest executive branch of the government authority of the subject of the Russian Federation) [4].

Following the establishment of the mixed electoral system for the State Duma of the Russian Federation, the mixed systems began to be established during the forming of the regional parliaments, a number of which has been elected exclusively using the proportional electoral system. An unspoken directive for this process became the changes to the Federal Law "On the general principles of the organization of the legislative (representative) and executive branches of the government authority of the subjects of the Russian Federation" from November 2 ${ }^{\text {nd }}, 2013$ [5] that have set a new ration of the number of deputies of the legislative (representative) branch of the government authority of the subject of the Russian Federation elected by proportional and majority electoral systems - the number of elected deputies by proportional system was lowered from $50 \%$ to $25 \%$. The proportional electoral system was changed to the mixed in the Amur Region and Yamal-Nenets Autonomous District. In the Moscow Region however, the transition to the mixed electoral system has already taken place back in 2011.

The mass acts of protest after the elections of 2011-2012 have also led to a partial refusal form the city manager, and the institution of city manager has received a negative grade from the Ministry of Regional Development of Russia [6]. The direct elections of the heads of municipal organization were returned in Blagoveshchensk, Verkhny Tagil, Volgograd, Yekaterinburg, Zarechnyy, Miass, Ulyanovsk, and other cities; the Irkutsk Region has passed a regional law on a local self-governance, setting direct elections for the heads and deputies of all municipalities [7].

At the same time, the analysis of the legislative and political practice testifies of the transformation of the passive electoral right carries an imitational character and preserves the ability of the government to affect the electoral process. The norms of the Russian electoral legislation continue to contradict the norms of the international law, including restrictions on participation in the elections of the citizens of the Russian Federation, who also have a citizenship of another country. The uneven requirements for the registration of candidates from the political parties at the presidential elections in the Russian Federation still remain, while the legislation continues to contain non-juridical terminology such as "impeccable reputation", which plays a part in the elections of the members of the Federal Council.

The registration of candidates for the Presidential Office of the Russian Federation puts the political parties that have representatives in the "lower" chambers of the federal parliament into an unequal position with the other political powers, thus continuing to violate the principle of equality of the members of the electoral process.

Within the cratological paradigm the placement of the lists of members of the Federal Council at the voting centers creates only the illusion of direct elections and does not have any political significance. The preliminary nomination of the candidates for the Federal Council increases the dependency of the regional leaders of executive power upon the interested parties, first and foremost, the Administration of the President of the Russian Federation, giving the latter a greater ability for controlling the electoral process. Taking into consideration the high level of the centralization of the Russian politeia the heads of the regions become the instruments in the formation of the federal elites, while their political future ends up in the hands of the political actors, capable of exerting significant influence upon the electoral process in the regions. In addition to that, using the idea of forming of the Federal Council of the Federal Assembly of the Russian Federation on the basis of "will of the voters" promotes positive attitude of the 


\section{Право и политика $6(186) \cdot 2015$}

population towards the direct elections as a more democratic mechanism for forming the "upper" chambers used in the US, Mexico, Brazil, Poland, Czech Republic, Romania, and other democratic countries.

Elections of the heads of the executive authorities of the subjects of the Russian Federation are accompanied by serious limitations that mitigate the passive electoral right of the citizens and allow the government to conduct the selection of candidates. This is how the post-protest legislation introduces the system of electoral "filters": once nominated, the candidate for the post of the head of the region must acquire the support of 5-10\% (usually 7\%) of the deputies of the representative municipal authorities and (or) the elected at municipal elections heads of municipalities of the subjects of the Russian Federation. Meanwhile, the candidate must be supported by the stated parties in no less than $3 / 4$ of the municipal areas and city districts of the subjects of the Federation. The signatures of the municipal deputies supporting a candidate for the position of the head of the subject of the Federation must have a notary seal ("notary filter"). As stated in the report "Direct elections of the governors and the system of gathering municipal signatures in 2012: influence upon the development of political system and directions of improvement" prepared by the Institute of Socio-Economic and Political Studies “...the filter is convenient for the federal and regional authorities as a mechanism for elimination of candidates, which can affect the practice of its implementation" [8, p. 9].

The so-called municipal and notary "filters" are the most discriminatory within the mechanism of the nomination of candidates for the post of the head of the subject of the Russian Federation. It is these "filters" that limit the prospects for development of regional political systems, allowing the current sitting regional leaders to completely control the electoral process.

In addition to overcoming the municipal and the notary "filters", the independent candidates must also collect the signatures from $0.5 \%$ to $2 \%$ of the voters. The exact percentage required is set by the regional legislation, and as a rule, it is usually the maximal. The obligation to gather the voter signatures after passing the municipal "filter" puts the independent candidates into uneven position against the "party" candidates, which also represents a discriminatory mechanism intended to prevent the registration of the candidates who are less dependent on the government. It is worth noting that at the September $14^{\text {th }}, 2014$ elections for the posts of the head of the subject of the Russian Federation a total of 207 candidates were nominated - 204 candidates from 42 political parties, and only 3 candidates running independently; 135 party candidates from 24 political parties were added to the election bulletins, and only 2 candidates that ran independently [9].

The post-protest legislation possessed a provision that allowed former heads of the subjects of the Russian Federation who have previously resigned their post, to be nominated again with the authorization of the President of the Russian Federation. This granted a significant advantage to the party candidates and further strengthened their loyalty towards the head of state. The greatest "innovation" became the ability of the President of the Russian Federation to initiate consultations with the political parties that nominate the candidates for the highest position of the subject of the Russian Federation, as well as with the candidates who are running for the same seat independently. The order of conducting such consultations was presented to the President of the Russian Federation. We can agree with I. L. Landau that “...the right to conduct consultations with the political parties that nominate candidates, as well as the candidates who are running independently, goes beyond his (President of the Russian Federation - auth.) authority. This power allows the President of the Russian Federation to get involved into the internal affairs of the parties; moreover, the ambiguity of the content of the very institution of consultations creates the conditions for its arbitrary implementation" [10, p. 31].

The Federal Law No. 303-FZ that set the new ratio of the number of deputies of the legislative (representative) branch of the government authority of the subject of the Russian Federation elected by the proportional and majority electoral systems has exempted from this norm the elections of the deputies of the legislative (representative) branches of the government authority of the cities of federal importance of Moscow and St. Petersburg - the two largest subjects of the Russian Federation. Within the Republic of Dagestan, Ingushetia, the Kabardino-Balkar Republic, the Republic of Kalmykia, the Chechen Republic, as well as the Kaluga Region, Tula Region, and St. Petersburg continue to maintain the fully proportional system of elections, which has been the subject of criticism from the political experts [11], and in K. Popper's opinion contradicts democracy [12]. The proportional electoral system halts the process of transformation of the regional political space, promoting the consolidation of elite groups, alienating the other candidates from participation in the realization of the passive electoral right and gives greater opportunities to the groups that stand higher on the ladder of the administrative resource.

The return to the direct elections of the heads of municipalities remains ineffective due to the violation of the fundamental principles of elections, including the noninvolvement of government into the electoral process. The biggest testimony to this is the results of the elections of 
the heads of municipalities - administrative centers of the subjects of the Russian Federation of September 14 ${ }^{\text {th }}, 2014$. In all of the municipalities - administrative centers of the subjects of the Russian Federation the victory belonged to the candidates who were supported by the heads of the regions. In the Amur Region and the mayor elections of the city of Blagoveshchensk the winner was A. A. Kozlov (38.68\%) [13]; in Sakhalin - S. A. Nadsadin (79.4\%) [14]; in Anadyr - I. V. Davydenko (83.08\%) [15].

A similar situation emerges in analyzing the results of the September $14^{\text {th }}, 2014$ elections for the representative branches of the municipalities. In all of the 21 municipalities the winners were representatives of the party "United Russia". On average the representatives of the "United Russia" have received approximately $70 \%$ of the deputy mandates in these representative branches. The highest results for the "United Russia" yielded the elections in Salekhard, Khabarovsk, and Penza. In these municipalities the party received over $90 \%$ of the deputy mandates.

In addition to that, the "liberalization" of the legislation pertaining to the passive electoral right was accompanied by implementation of new limitations. Among them is the law prohibiting citizens to exercise their passive electoral right after the expiry of their conviction - for felony offenders the term was set to 10 years, and for the most serious offenders -15 years after the expiry of their conviction, which not only contradicts the article 86 of the Criminal Code of the Russian Federation, but also contains an obvious political component. Taking into account the fact that in Russia amongst the most serious offenses are the crimes of extremist nature, while the notion "extremism" within the highly politicized Russian political system carries a non-juridical character, the revocation of the passive electoral right with regards to persons deemed "extremists" can testify to the increasing selective role of the government in the electoral process.

The Federal Law No. 40-FZ from May 2 $2^{\text {nd }}, 2012$ introduced the restriction upon previous heads of subjects of the Russian Federation to run for the same seat for 2 years if they were removed from their post by the order of the President of the Russian Federation, taking away the ability of such persons to prove or disprove the legitimacy of the President's decision by the electoral process. At the same time, if the removal of the head of executive branches of the regional authority took place based on the distrust from the regional parliament, the President has the right to allow the ex-head of the subject to be nominated for this post once again, providing that they have held their position for at least one year.

A negative trend in the sphere of the realization by the citizens of the Russian Federation of their passive electoral law became the Federal Law signed by the President of the Russian Federation on February $3^{\text {rd }}, 2015$ "Changes to the articles 32 and 33 of the Federal law "About basic guarantees of the voting rights and the participation rights in the referendum of citizens of the Russian Federation" and the Federal Law "On the General Principles of the Organization of Local Self-Governance in the Russian Federation"' [16]. The law implements the procedure for appointing mayors and heads of the districts, which practically deprives the citizens of the opportunity to be elected for these posts. These amendments also make it possible to appoint a mayor or a head of a district from the cabinet of municipal deputies. It seems that these innovations limit the passive electoral right of the citizens, strengthen the political influence of the governors and presidents of the republics upon the local self-governance, and attempt to prevent the situations that took place in Yekaterinburg and Petrozavodsk, where the mayor-elects were the representatives of the opposition Yevgeny Roizman and Galina Shirshina.

The transformation of the passive electoral right in Russia after the acts of protest "For Fair Elections" of 2012 has kept the aim of the ruling Russian establishment to prevent citizens from being elected to the highest posts. The persistent autocratic trend leads to the degradation of the Russian politeia, weakening of the feedback system, and causes mass frustration.

\section{Библиография:}

1. О внесении изменений в отдельные законодательные акты Российской Федерации в связи с освобождением политических партий от сбора подписей избирателей на выборах депутатов Государственной Думы Федерального Собрания Российской Федерации, в органы государственной власти субъектов Российской Федерации и органы местного самоуправления: Федеральный закон от 02.05.2012 41-Ф3 (с изм. от 22.02.2014) // Собрание законодательства РФ, 07.05.2012, № 19, ст. 2275.

2. О порядке формирования Совета Федерации Федерального Собрания Российской Федерации: Федеральный закон от 3 декабря 2012 г. № 229-Ф3. [Электронный ресурс] // URL: http://www.garant.ru/products/ipo/prime/doc/70171674/ (дата обращения: 25.02.2015).

3. О выборах депутатов Государственной Думы Федерального Собрания Российской Федерации: Федеральный закон № 20-Ф3 от 22.02.2014 (ред. от 24.11.2014) // Собрание законодательства РФ, 24.02.2014, № 8, ст. 740.

4. О внесении изменений в Федеральный закон «Об общих принципах организации законодательных (представительных) и исполнительных органов государственной власти субъектов Российской Федерации» и Федеральный закон «Об основ- 
DOI: $10.7256 / 1811-9018.2015 .6 .14975$

При цитировании этой статьи сноска на dоі обязательна

\section{Право и политика $6(186) \cdot 2015$}

ных гарантиях избирательных прав и права на участие в референдуме граждан Российской Федерации»: Федеральный закон Российской Федерации от 2 мая 2012 г.-№ 40-Ф3 //Российская газета-Федеральный выпуск от 4 мая 2012 ,-№ 5772.

5. О внесении изменений в отдельные законодательные акты Российской Федерации: Федеральный закон № 303 -Ф3 от 2 ноября 2013 г. // Собрании законодательства Российской Федерации от 4 ноября 2013 г. № 44 ст. 5642.

6. Назначены неэффективными. Минрегион против дальнейшего распространения института сити-менеджеров. [Электронный pecypc] // URL: http:/www.gazeta.ru/politics/2011/07/22_a_3703137.shtml (дата обращения: 25.02.2015)

7. Об отдельных вопросах формирования органов местного самоуправления муниципальных образований Иркутской области: Закон Иркутской области от 30.05.2014 № 11/5a - 3С.

8. Прямые выборы губернаторов и система сбора муниципальных подписей в 2012 г.: влияние на развитие политической системы и направления совершенствования: Аналитический доклад Фонда «Институт социально-экономических и политических исследований»,-Москва, ноябрь 2012 г. - 84 с.

9. Выборы-2014-Единый день голосования. [Электронный ресурс] // URL: http://azerros.ru/events-and-comments/20118-vybory2014-edinyy-den-golosovaniya.html (дата обращения: 02.11.2014).

10. Ландау И.Л. Выборы губернатора: Анализ федерального и регионального законодательства // Вестник Балтийского государственного университета им. И. Канта, 2013, - Вып. 9 . С. 30-36.

11. Кынев А.В. Пропорциональная избирательная система по-российски: ограниченная конкуренция и управляемая партийность // Российское электоральное обозрение, 2007.-№ 1. - С. 30-40.

12. Поппер К. Пропорциональная система противоречит демократии. [Электронный ресурc] // URL: http://www.democracy. ru/curious/democracy/Popper_democracy.html (дата обращения: 25.02.2015)

13. Официальный сайт Избирательной комиссии Амурской области. Выборы мэра г. Благовещенска. [Электронный ресурс] // URL: http:/www.amur.vybory.izbirkom.ru/region/region/amur?action=show\&root=1\&tvd=4284003263710\&vrn=4284003263706 (Rion=28\&global=\&sub_region=28\&prver=0\&pronetvd=null\&vibid=4284003263710\&type=234. (дата обращения: 25.02.2015)

14. Предварительные итоги голосования http://izbirkom.admsakhalin.ru/itogi_m_18/; Официальный сайт Избирательной комиссии Сахалинской области. В Сахалинской области состоялись муниципальные выборы. [Электронный ресурс] // URL: http://sakhalin.izbirkom.ru/isp/sx/art/963824/cp/1/br/929994.html (дата обращения: 25.02.2015)

15. Официальный сайт Избирательной комиссии Чукотского автономного округа. Выборы в органы местного самоуправления Чукотского автономного округа 2014 года. [Электронный ресурс] // URL: http://chukot.izbirkom.ru/isp/sx/art/950466/ $\mathrm{cp} / 1 / \mathrm{br} / 929124 . \mathrm{html}$ (дата обращения: 25.02.2015)

16. О внесении изменений в статьи 32 и 33 Федерального закона «Об основных гарантиях избирательных прав и права на участие в референдуме граждан Российской Федерации» и Федеральный закон «Об общих принципах организации местного самоуправления в Российской Федерации»: Федеральный закон от 03.02.2015 № 8-Ф3// Собрание законодательства РФ, 09.02.2015, № 6, ст. 886

\section{References (transliterated):}

1. Landau I.L. Vybory gubernatora: Analiz federal'nogo i regional'nogo zakonodatel'stva // Vestnik Baltiiskogo gosudarstvennogo universiteta im. I. Kanta, 2013,-Vyp. 9 . S. 30-36.

2. Kynev A.V. Proportsional'naya izbiratel'naya sistema po-rossiiski: ogranichennaya konkurentsiya i upravlyaemaya partiinost' // Rossiiskoe elektoral'noe obozrenie, 2007.-№ 1. - S. 30-40.

3. Popper K. Proportsional'naya sistema protivorechit demokratii. [Elektronnyi resurs] // URL: http://www.democracy.ru/curious/ democracy/Popper_democracy.html (data obrashcheniya: 25.02.2015) 